\title{
ANALYSIS OF NORMATIVE AND SOCIAL ASPECTS OF PUBLIC PROTECTION OF WAGES
}

\author{
C.C. Nenu
}

\section{Carmen Constantina Nenu}

Faculty of Law and Administrative Sciences, Department of Law and Administrative Sciences

University of Piteşti, Piteşti, Romania

*Corespondence: Carmen Constantina Nenu, University of Piteşti, 1 Târgul din Vale St., Piteşti, Romania

E-mail: carmennenu2006@yahoo.com

\begin{abstract}
The need to protect employee wages is based on the premise that these wages fulfill a vital function of maintenance and support of the employee and his family. Wage protection tools provided by the legislation seek to ensure the actual receipt of payment by the employer, either wholly or in a minimal part, even when their employer is in a situation of insolvency or inability to meet debt payment.
\end{abstract}

Keywords: payment, wages, employees, insolvency, work

\section{Introduction}

Salary is the main determinant of labor contract. In the case of this contract there are situations in which, although the prerequisites of its termination are not created, the employer cannot meet his primary obligation, that is, to pay wages because of insolvency. Insolvency is a contemporary reality, occurring often and being established and regulated as a means of protection and recovery of operators, so as to keep them on the competitive market. Maintaining them on the market implies the maintenance and protection of the employees of these operators and of their jobs. It is therefore important to understand and improve the mechanism of public protection of wages in the case of operators in insolvency, because this mechanism has both economic and social implications, both being particularly extensive.

\section{Methodology}

In order to properly understand the legal institution of public protection of pecuniary rights in the case of employees working in a company that is in insolvency, a presentation of normative regulations at European level is required, as well as one of the national legislation. An analysis of the way in which Romania has agreed to transpose the EU Directive in the field and also an analysis of the legislative changes in our country are essential. These legislative changes, although they have incidence in the field, are not clear regarding the applicability of the European standard. And here we are talking about the lack of legislative correlation when the act which regulates the financial crisis and the insolvency of administrative units was adopted ${ }^{1}$.

1.1 International and European regulations regarding the protection of pecuniary rights of the employees hired by employers in insolvency.

\footnotetext{
${ }^{1}$ Government Emergency Ordinance no. 46/2013, published in Official Gazette of Romania, Part I, no. 299 of May 24, 2013.
} 
Article 11 of Convention 95/1949 of the International Labor Organization ${ }^{2}$, established the wages protection mechanism based on the privileged position of the employee to other creditors of the employer. This article states that, in the event of bankruptcy or judicial liquidation of a company, the employees of this company will be considered preferential creditors. This refers to wages owed to them for services performed in a prior bankruptcy or judicial liquidation period, to be determined in accordance with national law, or to salaries that do not exceed an amount determined in accordance with national legislation. Salary that is a preferential loan must be paid in full before ordinary creditors can claim part of the company's assets. It is the role of national legislation to establish the priority relationship between the salary which is a preferential loan and other loans. In the Romanian law, according to art. 123 of Law no. 85/2006 on insolvency proceedings ${ }^{3}$, claims arising from employment relationships will be paid first after covering the costs of the insolvency proceedings.

Judicial proceedings for bankruptcy or suspension of payments of the insolvent employer generate an objective situation of uncertainty for employees of an employer in debt and, therefore, the European Union considered that it was necessary to create state institutions to guarantee the wages that would automatically provide employees immediate and direct collection of debt or at least part of their minimum ${ }^{4}$. These institutions substitute employees to require the insolvent employer that contracted debt collection. Therefore, the state must create a public insurance system of liabilities arising from legal work relationships. Internationally, there are at least three rules requiring the creation of a guarantee of salary, as follows:

1. At European level, the European Social Charter, revised 1996 law that establishes in article 25 that "work credits from contracts of employment or employment relationship will be secured by a guarantee institution or other effective form of protection";

2. In the European Union Directive $80 / 987 /$ EEC was approved, in this respect, subsequently revised by Directive 2002/74/EC on the approximation of the laws protecting the rights of salaried employees in case of insolvency of the employer, repealed by the entry into force of Directive 2008/94/EC.

3. At international level, within the International Labor Organization, Convention 173/1992 and Recommendation 180 were adopted, relating to the protection of wage credits in employer insolvency cases, which have not yet been ratified by Romania. By the adoption of Directive 80/987/EEC a rule was first established in European Community relating to the protection of employees in the situation of being in a legal relationship with an insolvent employer. The main aim of the Directive was not a social but an economic one, namely to ensure fair competition between companies of different EU countries in a single market, all under an obligation to establish and contribute to a fund to protect workers whose employer has been declared insolvent and has contracted debts to be paid to them. However, the Directive has had a clear social objective consisting in guaranteeing employees a Community minimum protection in the event of insolvency of the employer, without prejudice to more favorable provisions existing in the Member States.

Directive 80/987/EEC was subsequently revised by Directive 2002/74/EC which added new dimensions to the Community law. One new dimension is, for example, the legislative treatment of situations where an employee provides services successively or simultaneously in many EU countries and, therefore, there are several institutions that may be responsible in cases of unpaid wages after the declaration of insolvency of the employer.

\footnotetext{
${ }^{2}$ Ratified by Romania by Decree no.284/1973, published in Official Buletin, part I, no.81 of July 6, 1973.

${ }^{3}$ Published in Official Gazette of Romania, part I, no. 359 of April 21 2006, with subsequent amendments.

${ }^{4}$ For details of the reasoning that led to the Community law of Fund claims Guarantee, see M. Basuc, C. Nenu s.a Relaţii de muncă. Modul de curs, Labor Inspection and Social Security, Spain, RO-03/IB/SO-01PHARE Project, Oscar Print, Bucharest, 2005, pp.227-230.
} 
Subsequently, since the Directive 90/987/CEE had been amended several times substantially, it was encoded by the adoption of Directive 2008/94/EC. ${ }^{5}$

\section{insolvency}

1.2. The national regulation of employees' rights protection in the case of

Directive 80/987/EEC was transposed into national law by Law no. 200 of 2006 concerning the establishment and use of the Guarantee Fund for the payment of wage claims ${ }^{6}$. According to art. 2 of this law, the Guarantee Fund shall be used to ensure payment of wage claims arising from individual employment contracts and from collective bargaining agreements. These were concluded by employees with employers against whom final judgments of opening insolvency proceedings were given and against whom the measure of total or partial deprivation of the right of administration was taken, name insolvent employers. According to art. 3, paragraph 1 of Law no. 85/2006 on the insolvency procedure, the insolvency of the debtor's assets is a state characterized by lack of funds available for payment of due debts. The law also provides that insolvency is obvious when the debtor, after 30 days from the due date, has not paid his debt to one or more creditors.

By applying art. 4. 3 of Directive 80/987/EEC, the Romanian legislature established in art. 14 p. 1 of Law no. 200/2006, a limit for the State guarantee of the payment of wages, that is, three gross average wages for each employee. The Romanian legislator has set a time limit for protected labor rights, stating that by unpaid remuneraţionis covered for a period of three calendar months prior to the opening of insolvency proceedings. Claims arising from employment relationships, paid in case of bankruptcy, according to Law. 85/2006 shall be reduced by the amounts paid from the Fund for guaranteeing employment claims ${ }^{7}$. The national legislation guaranteeing wage claims establishes, under Community Law, legal measures related to the case of transnational employers. The preamble to the adoption of Directive 2002/74/EC has reported that, in order to ensure legal safety for employees in case of insolvency of companies which operate in different Member States, it is necessary to introduce provisions to explicitly establish the institution responsible for payment of unpaid wage claims of employees in this situation. Therefore, this directive introduced Article 8a, which provides that "when some business developed in at least two Member States is insolvent, the institution responsible for payment of unpaid loans is the one of the Member State where the business is done" and that "expanding employee rights will be determined by the lawof hired employees governed by the competent guaranteeing institution". The Romanian legislature established in art. 20 of Law no. 200/2006 that, in case of transnational employer insolvency, determining the amount of claims for employees who habitually perform their work activities in Romania and their payment is made by the territorial agency in whose employees operate. In determining the insolvency the judgment of the competent authority of a Member State of the European Union or of the European Economic Area will be considered, which opens proceedings or, where applicable, states that there are no goods owned by the debtor or they are insufficient to warrant the opening of insolvency proceedings and erasure from the register is decided.

\subsection{National regulations of administrative unit insolvency.}

For the first time in Romania, through the adoption of Ordinance 46/2013, the legal insolvency of administrative units was regulated, as a distinct legal institution of insolvency regulated by Law $85 / 2006$. According to the above mentioned normative act, insolvency is a state of the territorial administrative unit assets characterized by the existence of financial difficulties, by the severe shortage of cash on hand, which leads to the nonpayment of liabilities for a certain period of time. Insolvency is presumed, under the same act, in the case of nonpayment of wages arising from employment relationships and provided

\footnotetext{
${ }^{5}$ Published in the Official Journal of theEuropean Union no.L 283/36 of 28.10.2008.

${ }^{6}$ Published in Official Gazette of Romania, Part I, no.453 of 25 May2006, as amended and supplemented.

${ }^{7}$ SeeI.T.Stefanescu, Tratat de dreptul muncii, Wolters Kluwer Publishing House, Bucharest, 2007, p 594.
} 
in the budget of income and expenses for a period exceeding 120 days from the due date. The Order introduces a new legal institution, namely the financial crisis defined as a state of the territorial administrative unit assets characterized by the existence of financial difficulties, by the severe shortage of cash on hand, which leads to non-payment of liabilities, payable on a given period of time. The financial crisis is presumed, among others, in case of non-payment of wages under the local budget revenue and expenditure budgets of the institutions of local or county public services, as appropriate, for a period exceeding 90 days from the due date. Regulation of insolvency proceedings of territorial administrative units is similar to that applicable to the merchants, being triggered by the delivery by the bankruptcy judge of a reasoned decision of opening insolvency proceedings.

In the contents of the final and transient provisions of GEO 46/2013 adaptations of Law 273/2006 regarding the local public finance can be found ${ }^{8}$, but no reference to the guarantee of salary claims established by Law 200/2006 is made. This law excludes employees of public institutions from the application of the Directive.

\section{Results}

From the comparative analysis of national legislation on the protection of the rights of public employees hired by employers in a state of insolvency, especially after the latest legislative intervention which consists in adopting Ordinance 46/2013, with the provisions and purpose of the directive, the conclusion is that the domestic legislation does not fully meet the EU regulatory framework in the field. Some of these inconsistencies will be briefly stated as follows:

3.1. According to art. 1 paragraph. 2 of the Directive, Member States may exclude from the scope of the Directive claims of certain employees, based on the existence of other forms of guarantee, if they offer equivalent protection. As seen from the analysis of EGO $46 / 2013$, no other form of protection of employees' claims is offered if they are hired by territorial administrative units in insolvency, which means that the provisions of law 200/2006 should have been applied to them as well.

Moreover, according to Art. 2 paragraph 4 of the Directive, Member States may extend the protection of workers in situations other than insolvency. Consequently, since the introduction of the concept of the financial crisis in the case of territorial administrative units, legislature could have had the possibility, not the obligation not to create a public protection of wages in such situations.

3.2. Regarding the concept of employer, art. 4 letter a of Law 200/2006 defines it as the natural or legal person, excluding public institutions defined by Law no. 500/2002 on public finances, that can hire workers with an individual employment contract, as provided by Law no. 53/2003 - Labor Code. This definition clearly shows that public institutions, therefore territorial administrative units as well, are excluded. This exclusion represented at the time of adopting law 200/2006 a consequence of the fact that public institutions cannot be in a state of insolvency. But after adopting GEO 46/2013, stating that the territorial administrative units may be declared insolvent, the exclusion provided by art. 4 letter a of Law 200/200 no longer has a legal basis and is discriminatory and inconsistent with the purpose and aim of the directive.

3.3. According to the European Regulation, the employer is insolvent if a request has been made for the opening of a collective proceeding based on the insolvency of the employer, but, under the national legislation, the public protection of pecuniary rights in the case of employees intervenes in case against them final judgment for opening insolvency complete or partial withdrawal of administration rights has been rendered.

\footnotetext{
${ }^{8}$ Published in Official Gazette of Romania, Part I, no. 618 of 18 July 2006, with subsequent amendments
} 


\section{Conclusions}

From the brief presentation of the current regulatory framework, what can be drawn is that the Romanian legislation is more restrictive than the European legislation, which leads to discriminatory treatment between employees of employers who are insolvent, on the one hand, and between them and those of the employers who are in a position of cessation of payments or insolvency. Social implications of lack of regulation in the case of public protection of wages, in the mentioned situations, are significant because employees are deprived of their fundamental right, that is, to receive their salary for the work performed in critical situations and to maintain their job. Therefore, it is suggested that the legislator should consider the principle of non-discrimination of both employees and employers as a fundamental principle of labor law. Moreover, another aspect to be considered is related to the social consequences of the current legal regulation of public protection of employees' rights, when their employers are unable to fulfill their obligation regarding the payment of wages.

\section{Bibliography}

I.T.Stefanescu, Tratat de dreptul muncii, "Wolters Kluwer" Publishing House, Bucharest, 2007.

M. Basuc C. Nenu and others, Relaţii de muncă. Modul de curs, "Oscar Print" Publishing House, Bucharest, 2005. 